0-644 後腹膜経由の回腸十二指腸瘦を術前に診

断しえたクローン病の一例

広島大学病熊制御医科学講座外科 ${ }^{1}$, 兵庫医科大学感染 制御学講座 ${ }^{2)}$

曽我祐一郎"，大毛宏喜"，，竹末芳生")，鬼武美幸"1,

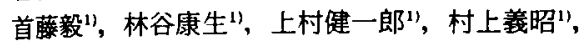

末田泰二郎1)

【背景】クローン病における十二指腸の瘦孔形成は，見 落とせば術後の膵液漏出により重篤な合併症につなが る.今回複雑な小腸間の内瀆から十二指腸に炎症が及ん でいた症例を経験し，術前に診断し得たので文献的考察 を加えて報告する。【症例]35歳女性. 下痢で発症しク口 一病と䛦断され，栄養療法を中心に内科的加療を約 10 年間行っていた。今回腸閉塞症状が出現し, 手術目的に て紹介となった.CT上小腸が一塊となっており，小腸透 相に少なくとも3 万所の小腸間で内瘦形成を認めた。 大腸病変は認めず小腸切除予定としていたか，体外式消 化管超音波検査にて，十二指腸と小腸との懹孔形成が疑 bれ，低聚張性十二指腸造影にて水平脚と小腸間に内俵 を認めた。内視鏡では十二指腸のつローン病所見は之し く，小腸病変加らの波及と診断した。開腹所見では一塊 となった回腸から，後腹膜を経由して十二指渴水平脚に 内㢈を形成していた。手術は小腸切除とをもに十二指腸 の楼状切除，縫合閉鎖を行い術後経過は良好であうた。 【考察】小腸病変加ら内瘦形成は, 小腸, 大腸, 膀胱 などが多いが，本症例のように十二指腸にも生しうる。 しかし後腹膜释由で理孔が延びている場合は術前診断が 困難で，術後の合併症につながる可能性がある。病悩期 間の長い症例ては, 予想外の部位に瘦孔を形成している 可能性を念頭に置いた術前評価が重要と考える。

0-645 術後穿孔を併発した simple ulcer の 1 例 市立宇和島病院外科

松本康志，岩川和秀，三好麻衣子，飯森俊介，佐藤創， 井上仁, 吉川浩之, 清地秀典, 岡田㥶三, 坂尾寿彦, 梶原伸介

回盲部谓瘍にて腹脫鏡補助下回盲部切除後穿孔を併発し た simple ulcer の症例を経験したので報告する。症例； 55才、女性。既往歴：B 型肝炎キャリアー、HTLVキャ リアー、15年前より踹息、狭心症、5 年前よりホシキン 病にて化学療法、3 年前、2 年前に下血あり。家族歴： 母 ATL、弟肝荿癌。現病歴; 平成18年 2 月21日下血あり 近医受䛦、胃力メラ異常なく大腸力メラにて回盲部に淟 慯性病変あり。下血持続するため2月24日当院紹介され た。消化管出血再燃の可能性と ATL の初期像の可能性 もあったため平成 18 年 3 月17日腹腔鏡補助下回盲部切除 を施行した。切除標本てはパウヒン弁に降接する潧㾂の ほ加回腸末端にも多発溃愓を認めた。術後2日目上り38 度前後の発熱が続き法後6日目にドレーンより嗄液の流 出を誏め吻合不全が疑われたため術後8日目に再手術を 施行した。開腹すると吻合部の肘門側がほ便全周性に離 開しており右半結腸切除術を施行した。切除標本では吻 合部に全周性の潧瑒と大型の穿孔を認め、小腸、大腸に 多発渣瘍を諮めた。この時点て simple ulcer、あるいは Behcet 病を疑い、ステロイド投与を開始した。病理では 初回手術時、再手術時の標本とも simple ulcerまたは Behcet 病に合致するとの所見であっだ。特に再手術時の 病理では回腸及び大腸の多発溃瘍は smからssに達し ており穿孔寸前の洪場も複数認められた。原因不明の回 盲部淇場は simple ulcerあるいは Behcet 病を念頭に置 く必要があると思われた。

\section{0-646 放射線照射性腸炎との鑑別に難渋した謴}

瘍性大腸炎の 1 例

筑波大学消化器外科

益子一樹, 山本雅由, 池田直哉, 高野恵輔, 柳澤和彦, 大河内信弘

症例は58歳，男性，2003年 5 月18日頻尿，残尿感を自覚 し, 近医受診。検査で膀脱と診断されたが, 膀胱温存 希望し, 6 月20日より放射線化学療法 $(50 \mathrm{~Gy}+\mathrm{CDDP})$ 開始 2004 年10月14日再発加認められ，経尿道的膀胱腫 瘦切除術 + 化学療法施行.2005年 9 月20日再々発を認め, 経尿道的膀腅腫瘍切除術施行。しかし瘦の遺残を認め, 11月24日当院泌尿器科受診. 多臓器に転移がないため, 膀睄全摘術目的で12月13日入院。入院後，下血を認め， 当院消化器内科を紹介され，大腸内視鏡唡查を施行し， 粘膜の充血, 易出血性，狭窄を認めた。放射線照射の既 往があり, 病変部が直腸と一部のS 状結腸に限局してい たため，放射線照射性腸炎と猃断された。下血が続き， 全身状態が不良のため，膀悓に对する一期的な手術が困 難と判断し，当科紹介となり，2006年1月11日に横行結 腸に人工肛門を造設した。術中横行結腸の粘膜に異常は 認めなかった。年後全身状態改善し，2月16日に当院 泌尿器科で膀胱全摘術が施行された.1 月後横行結腸の 人工肍門の周囲皮它が-部離開し、粘膜のびらんを認め たため，大腸内視鏡検查を行い，直腸から上行結腸まて

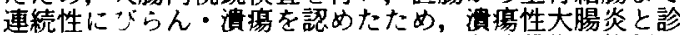
断し，3月31日結腸全摘・回腸人工肛門造設術を施行し た。放射線照射の既往がある腸炎では，謴場性大腸炎と の爁別ができけ，治療が遅くなり，重第な状悲になる可 能性があるため，注意を要する。

0-647水痘、偽膜性大腸炎を併発した若年性涄 瘍性大腸炎手術の 1 例 岡山大学医学部齿学部附属病院消化管外科

小林直哉，岩垣博巳，金沢卓，唒本良夫，田中紀章

【目的】謴瘍性大腸炎 (UC)に対する内科的治療として、 従来の 5-ASA 製剂、ステロイド、免废抑制刜などの薬 物療法に加えて、白血球除去療法が保険適応になってき た。こうした治療に反応し、緊急手術が回避できた症例 が多々あることも事実であるが、時に日和見感染症が併 発して重拝化することがある。今回、我々は、水痘、偽 膜性大腸炎を併発した若年性 UCにて手術に至った症例 を経験したので報告する。【症例】15崴の女児で、初発 症状は血便下痢て、病悩期間は 7 ヶ月であった。UCに て、ペンタサ、ステロイド、イムラン、ネオーラルにて 加療するも改善無く、当院を紹介された。入院後、水痘 を発症し、その後、腰椎压迫骨折、さらには偽膜性大腸 炎を併発した。CRP15.5ng/ml と上昇し、メガコロンを CTにて認めたため、内科的治療の限界と判断し、平成18 年 2 月16日に緊急手術を施行した。【成續】大腸严全摘十 $\mathrm{J}$ 型回腸肛阿管吻合術 (IACA) + 回腸婰造設術を施行 した。リガ・シュアーを有効に使用し、手術時間は 3 時 間 5 分であった。術後経過は良好であった。術後 3 ケ月 目にストーマ閉鎖を行い、その後漏便もなく括約筋機能 も良好である。現在、ステロイドフリーで、成長状態も 良好である。【結論】水痘、偽膜性大腸炎を併発したUC 症例を経験した。UC患者には、こうした日和見感染症が 発症することを念頭においた注り泻い管理が重要であ る。 
0-648

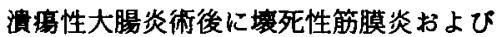

壊瘨性䐬皮症を合併した 1 例

福岡大学第一外科

米良利之, 田中伸之介, 牧孝将, 松尾勝一, 安波洋一

症例は42葴男性。下痢、下血を主訴に近医を受診。下部 消化管内視鏡にて溃場性大腸炎 (UC) と診断され入院と なった。サラソピリン内服による保存的治療が施行され たが、症状改善しないため当院の消化器内科に転院、内 科入院後UC重症例と判断され、ステロイド療法 (プレ ドニソロン $60 \mathrm{mg} /$ day)が開始された。しかしながら入院 6 日目頃より腹痛增強、X線、CT て横行結腸の著明㹡張 (>6 cm) を記めたため中毒性巨大結腸症の合併と診 断、当科転科のうえ㗨急手術となった。大腸は全体に発 赤、腫脹強く、横行結腸は約 $13 \mathrm{~cm}$ 幅に高度㹡張、腸管壁 は非常に翡薄化していた。可及的に結腸严全摘、S 状結腸 粘夜瘦造設、回腸樭造設術を施行した。術後経過は順調 でちったが、術後て日目頃より右大駺部に発赤出現、発

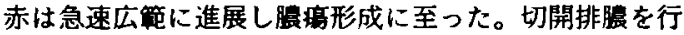
うも炎症はさらに搪大、術後の堙死性筋膜炎の診断にて 術後11日目に䋈急手術(皮间切開、デブリードマン) を 行った。同部は順調に回復したが、その数日後より回晹

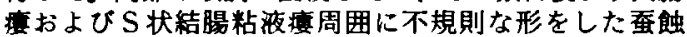

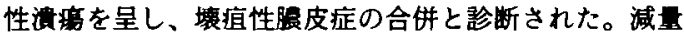
中のステロイドを再度增量、壊瘨性䝢皮症の改善を待っ て術後33日目に分屏植皮術を施行した。UCに中毒性巨 大結腸症、滾死性筋膜炎、壤㾇性腿皮症を合併、治療に 大变難涉した症例を経験したので若干の文献的考察を加 え報告する。

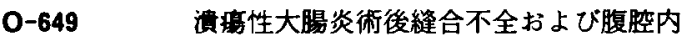 血腫による腹膜炎をきたした一例 \\ 東邦大学医療センター大森病院消化器外科 \\ 栗原聰元, 後藤友彦, 新井㹂一郎, 牛込充則, 渻藤直康, 松本浩, 小池敦一，岡本康介，船橋公彦，金子弘真， 寺本龍生}

症例は64葴男性、傮鹪性大腸炎のため 20 年間当院の外来 に通院し、ステロイド斉の内服治撩を受けていた。平成 14 年 5 月より腹痛、下血が出現したため外来受診し溃凝 性大腸炎の急性增悪々診断され入院となった。入院後の 大腸内視鏡検㚗ては下行結腸から直腸にかけて強い炎应 所見を認め、さらにS 状結腸には全周性の狭究があり、

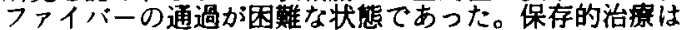
限界々判断し 6 月に大晹垔全摘術兼回腸 J パウ千造設術 を施行した。術後 8 病日に腹痛、発熱お゙さひ左上腹部に 腹膜刺教症状を証めたため術後の維合不全による腹膜炎 を疑いドレーシ造影施行した。造影模查て綎合不全は認 めたしののドレナージは良好であり獥部所見と一致しな かった。腹部 CTを施行したところ左上腹部に高吸収域

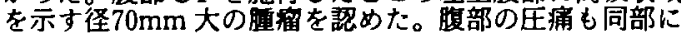
一致したことから術後の腹腔内血随に感染を来したもの と彭断し、抗生風で保存的に治療を開始した。腹膜炎は 限局化したものの炎症所見消退せず、第14病日にエコー ガイド下に穿刺ドレナージ術を施行した。ドレナージに 上り炎症所見は消退、縫合不全も保存的に治虑し退院と なった。消搒性大腸炎は術前にステロイド等が投与され ており免疫扸制状態にある。このような患者て術後に腹 膜炎症状を示した場合縫合不全以外の感染が生すること 考十分念頭に入れて術後経過を追う必要があると考えら れた。
0-650 サイトメガロウイルス腸炎を併発した湿
痬性大腸炎の一手術例とその文献的考察
岡山大学医学部歯学部附属病院消化管外科
小林直哉, 岩垣博巳, 猶本良夫, 田中紀章

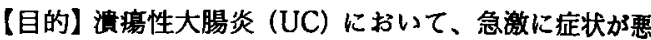
化する例や、ステロイド郕の投与や血球成分除去療法の 実施や免疫抑制堉の投与などのあらゆる治療を行なって も効果が見られない例においては、日和見感染症として サイトメガロウイルス (CMV) 感染陽炎を合併している ことが多いことが近年判明し、CMV 腸炎が UC の難治 化や重症化に大きく関わっていることが示唆されてい る。今回、CMV 腸炎を併発した UC 手術症例を経験した ので文献的考察を含めて報告する。【症例】症例は33藏 のUC男性て、近医にて PSL80mg、LCAPにても腹痛、 下痢、下血が改善せず、当院へ紹介となった。CFにて全 大腸にわたる多発性の不整形潰瘍と punched-out ulcer を認めた。生検て CMV 核内封入体は㭘出されなかった が、CMV 抗原血症 (C 7-HRP、C10) 陽性て GCV 投与 で腸病変が軽快した。全身状態の改善を計った後、手術 (大腸严全摘、IACA (ileal-pouch anal canal anas tomosis) +DI (diverting ileostomy)) を施行した。術 後経過は良好で、72日後にDI の閉銷を行い、現在社会復 㷌をしている。【結論】UCの急激悪化例や治療無效例に 対しては早急に CMV 感染の検查を実施すべきであり、 重症 UC 患者に対する CMV 腸炎の早期の診断と適切な 治療の夷施が重要である。

\section{0-651}

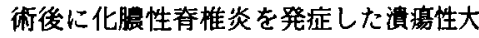

腸炎の 1 例

徳島大学外科

後藤正和，吉田卓弘，宇山攻，松岡永，山井礼道， 清家純一, 本田純子, 梅本淳, 島田光生, 丹黑章

症例は54歳、男性。腹痛、下血、発熱で発症し、2ヶ月 程度のステロイド治療にて加療するも抵抗性にて緩解が 得られなかった。その後、LCAP (白血球除去療法)、艺 イトメガロウイルス感染に対する抗ウイルス療法などの 内科的治療にも奻果を認めなかったため、全大腸型の難

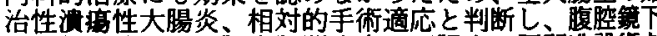
全大腸切除術、回腸点肛門吻合、回腸人工肛門造設術を 施行した。術後 3 週間経過した頃に突然の腰部の激痛か 出現、発症時の腰部 CT、MRI では軽度の椎間板変性を 疑う所見を認めるのみであった。その後MRSA 敗血应、 ARDS 乞と進行した。集学的治療により全身状態の改善 を認めた後も発熱が持続するため全身 CTを撮影したと ころ、腰椎椎間板炎とそれに伴う花朖性脊椎炎を疑われ た。Ga 炎症性シシチグラフィーでも腰椎の一部に限局

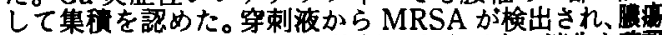
の経皮的洗净ドレナージを施行。炎症反応の消失を礁㵊 した。惯性大腸炎における筋・骨格系の腸管外合併症 としては強直性春椎炎、仙腸関節炎などが知られている か、化滕性脊椎炎は非常に稀な合併症である。化脸性春 椎炎は compromized host に発症するものであり、自䱾 例では術前の便培落て MRSA が検出されており、周術 期にはバンコマイシンの投与を行っていたにもかかわら 守哞症した。溃病性大腸炎の合併症として化儤性脊椎炎 は犁ではあるが、十分に起こりうる合併症であると考え られた。 
0-652

当院における痔核治療の選択

八子医院外科

八子直樹

く緒言〉寿核手術については結禁切除法（LE）を標準術 式として、適応を検討した上で PPH 法や出血軽減をは かるへく超音波メスも使用している(HS 法)。またジオ ン四段陼注射療法も䢝入した。治療手技〉（LE 法）： 切除にあたりそのデザインが最重要である。肛門上皮切 除恬最小限とし、肛門クッションの可及的温存を心がけ ている。(PPH 法)：脱出を主訴とする全周性内庤核、粘 膜脱症例が適応となる。術式のポイントは巾着縫合と術 後出血予防である。(HS 法)：切除範讲を検討し、半閉鎖 に準じて吸収系による粘膜縫合を加えている。(ジオン注 射療法)：治療にあたっては十分な同意の下に四段階注 射法を行っている。<治療成績 > PPH 法92例中 3 例にて 術後 5 日目以降に止血を要する出血があり、また 3 例て 街後 3 か月以上経過後追加処置が必要であった。HS 法 215例中 2 例で後出血を経験したが、半閉銷を票入以降出 血例はなかった。ジオン注施行 55 症例中単独投与の32症 例について投与後症状改善率は（脱出）30中ほほ改善22 例、軽快 8 例、(出血)16例中全例で改善がみられた。治 㬌 1 か月後の患者満足度調査では大変満足 22 例 $\left(68.8^{\circ}{ }_{0}\right)$ 满足 8 例 $\left(25.0^{\circ}\right)$ ），やp不満 1 例 $\left(3.1_{0}^{\circ}\right.$ ) 不満 1 例(3. 1\%)であった。結語＞庤核治療にあたっては正確な診 断と各種治療法の説明と同意が不可欠である。手術療法 については適応と術後長期成績の検討が、ジオンについ ては長期経過の観察が必要と考える。

0-653 ジオン硬化療法による庤核治療の検討

\section{市立伊丹病院外科}

岡崎誠，炏山洋介，川崎敬二郎，高山治，木村文彦， 三好秀幸, 山本正之, 平塚正弘

【はじめ:】OC一108は硫酸アルミニウムカリウムおよ

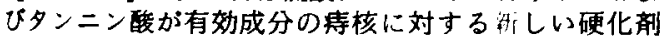
(商品名ジオン)である。当院では今年 1 月より脱肛が主 症状てある庤核に対しジオンによる硬化療法を開始し た。【対象】本年 1 月より 5 月まてにジンによる硬化竟 法を施行した24例である。年龄は33歳から86歳であった。 対象症状は 脱肛を伴う内庤核が主であるが、直腸脱や ホワイトヘッド後粘膜脱にも各 1 例づつ行った。【手技手 順了麻酔は全例を局所麻酔で行った。患者を右側卧とし、 局所麻醉徭、ジオン専用の肛門鏡を用いて 4 段階法注射 にて施行した。ジオンの使用量は $20 \mathrm{cc} 〜 40 \mathrm{cc}$ の間であっ た。【思者管理】処置前日入院で 2 泊 3 日入院であった。 また絶食は当日の昼のみであった。初めての症例から2 例だけが術後 2 日間入院したが、その後は全例、翌日退 院とした。【合併症】24例施行したかきりでは合併症は 1 例もなかった。【アンケート調查】術後 1ヶ月をめどに患 者に满足度などのアンケート調查を行った。【結語】内麻 核に対するジオン硬化療法は患者の满足度も高く、今後 従来の結热切除手術にとってかかる可能性がある治療法 と考えられた。

\section{O-654 \\ 庤核上直腸粘膜ゴム輪結热術による新し}

い内庠核治療

新潟大学消化器 - 一般外科学 ${ }^{11}$, 県立吉田病院外科 ${ }^{21}$

谷達夫"), 岡本春彦 ${ }^{2}$, 島田能史 "), 小林康雄 ${ }^{11}$, 龟山仁史"), 野上仁"1, 丸山聡"，飯合恒夫"，畠山勝義"

【背景】コム輪バンドによる内痔核結桇術は、痔核根部 にコ蜦をかけ庤核を壊死脱落させる、外来で施行可能 な簡単な治療法てある。一方、PPH 法は、庤核は温存し その口側直腸粘膜を環状に切除、絴合する治療法である。 その原理は脱出した持核組織を従来の位置に吊り上げ固 定、同時に粘膜離断に上る血行遮断を行い庤核の自然退 縮を促すものである。我々はPPH 法の原理に基づき、ざ 么输結架術を用いて内痔核口側の直腸余剩粘膜を縫縮す る新しいコム陯結紫法を行い、良好な結果を得ているの で報告する。【対象】2002年から2006年に当科外来で保存 的療法を行うも脱出や出血などの症状加残存し外科的活 療を希望した Goligher分類第 II III 度の有症状例18 名。【方法】通常の肛門鏡下に脱出あるいは出血の原奶七 ある内庤核を同定、そのП側の正常粘膜をコム輪結督己 䋖縮。脱出あるいは出血存きたす内持核が複数ある埸合 は、同棣に複数力所の維綰索行い最大で 5 力所ゴ公輪絬 禁を行つた。【結果】術後台併症として軽度から中等度の 肘門痛 (10例)、軽度の出血 (8 例) が認めら九たが、術 後 1 週間後にはいすれれ消失。1 例、施行後に脱肛嵌顿 あり結帒切除術が施行された。15例に症状の改善を認め た。【考察】本法は外来で行うことが出来る简便な手技て あるが、磨核治療として医めて合目的であり、低侵裂か つ安全て有奻性の高い手技と考えられる。今後症例を重 ね、長期成續、再発等について検討したい。

\section{O-655 超音波凝固切開装置を使用した内麻核治 療の検討}

医療法人社団涼友会九段下D，S，マイクリニック"，医 療法人社団涼友会執行クリニック ", 医療法人社団涼友 会神楽坂D．．マ、イクリニック ${ }^{31}$

松橋亘 ${ }^{11}$, 執行友成 ${ }^{21}$ ，東博敏 ${ }^{31}$ ，永田傳 ${ }^{31}$, 高島格 ${ }^{31}$

内庤核治療の原則はその本体である肛門粘膜下の静脈瘤 の血流を遮断することにある。術式としては結热切除術 で完成しているが、術後の疼痛、腫脹、出血が問題とな り、入院期間の延長に慗がる。さざま手技上の】夫 もこれらの合併症の克服が目標である。今回我々は超音

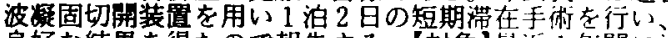
良好な結果を得たので報告する。【対象】最近1年間に治 療した内素核11例て、全身麻醉下に超音做㠜湖切開装置 を用いた結势切除術を行なつた。【方法】以たり項目て検 討を加えた。性別、年龄、術前症状(出血、㹣痛、腫脹・ 脱肛を各 1 点として症状指数と表す)、Goligher 分類、庤 核数、手術時間、術後の症状改善率(術前後ひ)指数し差/ 術前指数)。【結果】男性 7 例、女性 4 例。年脚は58.63土 17.51葴であつた。術前症状は平均1.91土0.70点です た。全例 Goligher 分類は 3 度であった。将核数は2.09士 0.83 個であった。手術時間は $22.27 \pm 7.20$ 分であり、1 庤 核あたりの手術時間は11.36士3.62分であった。術後 3 日

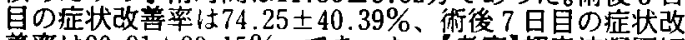

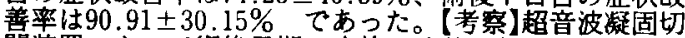
開装置によって術後早期に症状の改善が認められた。そ の要因は粘膜下・皮下組織一の過剩な物理エネルギーに よる損賃が避けられ、循謤障害が軽微で早期に治㦄機転 が働いたものと考えられえた。 
0-656 侍核根治手術における術後合併症の検討 松島病院大腸肛門病センター

霧生孝司，松島誠、下島裕寛，田中良明，柳田謙蔵， 鈴木和徳

【緒言】痔核根治手術の術後合併症には創部出血、肛門 狭窄、創部感染等があるが、特にその中で創部出血は予 湘できないものでかつ迅速な判断、対応を必要とし、最 も注意を要する合併症である。今回、当院の術後合併症 について検討を行った。【対象・方法】2005年 1月～7月 に当院に执いて施行された庤核結絷切除術1263症例（男 性：662例、女性：601例) を対象に術後合併症の検討を した。【結果】創部出血は 32 例 $(2.53 \%$ )、肛門狭窄は 12 例 $\left(0.95_{0}^{\circ}\right)$ 、創部感染等は 9 例 (1). $\left.71 \%\right)$ 認めた。そ のうち術後出血では、腰椎麻酔下での止血手術を要した 症例は28例 (2. 220\%)、局所麻酔下て止血手術を施行し た症例は 4 例 (11.32\% ) で、特に、術後 3 日以内の出血 を早期、術後 6 日目以降を晚期出血とした所それそれ 10 例 $(0.79 \%$ ）、22例（1．74\%）であった。肛門狭窄ては 街後に拡張ブジーを行ったものは10例、内括約筋切開を 行ったものは2例であった。又、術後創部感染にはドレ ナージ創作製等を行っている。結論】他の合併症に比心゙、 術後出血は時に重第な合併症と成り得る事から、術後管 理、follow up は重要と考えられた。又、術後晚期出血は いろいろな要因で起こると考えられるがいまだ明確な原 因はわかっておらず、常に risk factor 在考え、また術後 出血の于防に対し工夫、対応等を考えていく事か肛門科 診療:は大切こある。

0-657 当院における庤核治療に関する検討

渡辺病院外科

松本欣也, 中川建夫, 渡辺英生

【はじす：二】当院こひ）庤核治療は結禁切除法 (半閉銷術) を基本として、数年前よりPPH 法を尃入し、また最近て は消寿需あるいはジオンによる硬化療法も行っている。 そこてこここ数年の術式の動向や、術後アンケート調查に よる各術式の成績について検討を行った。【対象と方法】 最近 5 年間における庤核治療における各術式の割合につ に: 学栝討した。また術後 1 年目のアンケート調查を中心 に各術式の满足度、排便時出血や疼痛の有無、soiling 症 状の有無などについて検討した。【結果】以前は結禁切除 法 (半閉銷術) が多かったが、2001年頃からは全国的な PPH 法の普及に上り当院でも $\mathrm{PPH}$ 法が增えてきた。 $た 2004$ 年が，は硬化療法も增之始め、現在:

(半閉鎖術) と消庤篮あるいはジオンによる硬化療法が 持核治療の中心となっってる。PPH 法は適応を外持核の ない 3 度の全周性脱肛に限局していることや、混合猃療 として治療を行むなければならないことにより最近は少

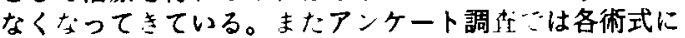
おける满足度は高く、他の検討項目についてもほとんど 差を認めなかった。【結語】結热切除法 (半閉銷術) は根 治性、PPH 法は術後疼痛の軽隇、また硬化療法は入院期 間の短縮なら゙において他の術式よりすぐれている。それ それの術式において根治性や満足度は高く、痔核治療に おいてどの術式を選択してもよいと思われるが、各症例 のニースに応じた術式の選択が必要と思れれた。
0-658

宿便性 S 状結腸穿孔の 1 例と本邦・欧米 報告例の文献的検討

東京大学腫瘍外科

西川武司, 堀信一, 名川弘一

症例は75歳男性。慢性的に便秘であり、腹痛を主訴に来

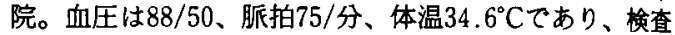
所見では WBC6700/ $\mu 1 、 C R P 0.55 \mathrm{mg} / \mathrm{dl}$ であった。腹部 全体の圧痛あり。CT 上 free air を認め、また大腸内に萁 便を多量に認めた。S状結腸部の穿孔を疑い、同日㗨急手 術となった。開腹すると、硬便で著明に拡張し穿孔をし た S状結腸があり、腹控内に䔬便が多量に存在した沉発 性腹膜炎の状態であった。穿孔部を含めて S 状結腸を切 除し、人工肛門を造設した。病理では $\mathrm{S}$ 状結腸に $3 \mathrm{~cm}$ 大の穿孔部があり、組織学的には穿孔部での粘膜・箭層 の断裂と穿孔部周辺粘膜の压迫壤死および好中球を主と した炎症細胞浸潤と出血を認め、宿便性 S 状結腸穿孔と 診断した。術後、敗血症性ショック、呼吸不全、DICを きたしたが改善した。今回、宿便性 S 状結腸穿孔の 1 症 例を経験した。本邦報告症例と欧米報告の文献的考察を 交えて報告する。

\author{
0-659 Ehlers-Danlos 症候群患者に対する結 \\ 腸穿孔 2 回の手術経験 \\ 昭和伊南総合病院外科 \\ 駒律和宜，横山隆秀，森川明男，林賢
}

今回われわれは 1 人の Ehlers-Danlos 症候群（以下 EDS）患者に対し、結腸穿孔 2 回と瘁着性イレウス 1 回 の手術を経験したので報告する。症例は男性、家族歷と して父が大動脈的破裂で術死。既往歴として2001年に両 側気胸・左血胸。2002年12月 (27歳)、右下腹部痛を主訴

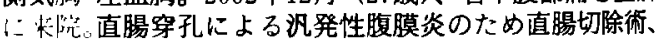
$S$ 状結晹瘦造設術を施行。術後第64病日退院。家族尓加 EDS か疑われ、遗伝子検查にて EDS, vascular type と 診断。2003年 6 月 (28歳)、腸閉塞にて入院となり保存的

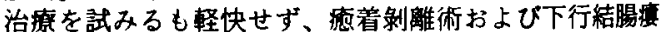
造設術を施行。術後 9 日目に内腸骨動脈からの出血を認 め、interventionalに止血術を行った。血腫による両側水 腎症および腸管の通過障害を発症し、ステント留置、陣 瘦開放により改善し第67病日退院。さらに2006年 1月(31 紫)、上腹部痛にて来院。横行結腸穿孔による汎発性腹膜 炎にて下行結腸・横行結腸左側切除、小腸部分切除、横 行結腸疸造設術を施行。術後に腹膜炎要延お゙よび右気胸 を認めたか、術後第84病日退院。定期的外来通院中てあ る。原因のはつきりしない消化管穿孔や腹腔内・後腹膜 血腫では、稀ではあるが本疾患を念頭におく必要がある。 また、本症例では組織の脆弱性を考虑した手術と、㡙重 なfollow upが必要であると考えられた。 
例

東海大学消化器外科

岡田和丈, 貞廣茌太郎, 幕内博康, 前田裕次, 鈴木俊之, 安田聖栄

私達はバリウムによる上部消化管造影(Barium meal： BM) 後の合併症としてまれな大腸穿孔4例を経験した ので報告する。

症例 1 : 36 瓷女性。 BM 2 日後に下腹部痛. 腹膜刺激症 状があり X-pでS状結腸，直腸にバリウムの貯留，CT で後腹膜に遊離ガス像を認めた。手術ではS状結腸間膜 内にバリウムの眝留を伴う $7 \mathrm{~cm}$ 大の樶疸形成，S状結 腸に $2 \mathrm{~cm}$ 大の穿孔を認めた. S 状結腸切除術を施行。 庭例 $2 ： 68$ 歳女性. BM 3 日後に腹痛, 発熱が出現し 6 日目に受診。下腹部に㽵痛あるも腹膜刺激症状なく、X一 pて直腸内にバリウムの貯留, CTてS 状結腸腸間膜, 後 腹膜に遊離ガス像を認めた。保存的に治療したが22日目 に手術.S状結腸に1.2×1.6 cm の穿孔を認めた.S状結 腸切除街を施行

症例 $3: 75$ 歳女性，BM 2 日後に腹痛，X-pて横行結腸

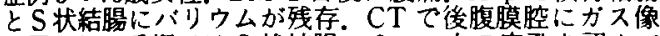
を証めた。手術ではS 状結腸に $3 \mathrm{~cm}$ 大の穿孔を認めバ リウムを伴う便が後腹膜へ漏出. S 状結腸切除術を施行. 症例 4:49歳男性. BNI 日後に腹痛. 腹膜刺激症状, X-pで遊離ガス像, 全結腸にパリウムの貯留, CTで遊灕 ガスを㒛めた。手術では S 状結腸に $1.8 \mathrm{~cm}$ と $1 \mathrm{~cm}$ 大の 穿孔を認めバリウムと便が腹腔内に㴜出. S状結腸切除 術を施行。

BM 後の結腸穿孔はいずれもS状洁晹で漏出範囲はい ずれも限局性で予後は良好てあっった。診断にはC它が有 用でちった。

0-661 大腸穿孔症例の検討

NHO 受医療センター中国がんセンター外科

清水洋祐，小関萬里，吕田奈央，橋本安司，山田大作， 桑田垔希，藤井亮知，寺本成一，宮本和明，黑住和史， 富永春海，㚼中信良，上池涉

目的・対象：1997年 4 月から2006年 3 月まてに当科で経 駼した大腸穿孔33例について検討した。結果：平均70.9 歳 (28～98歳)、男17例、女16例、原因は、大腸癌 9 例、 特発性 9 例、咊室炎 8 例、謴瘍性大腸炎 1 例、医原性 5 例、穿孔部位は盲腸 1 例、上行結腸 5 例、横行結腸 1 例、 下行結腸 2 例、S 状結腸18例、直腸 6 例、穿孔形式は遊離 型19例 $(57.6 \%)$ 、被覆型14例て、術前 free air を認めた ものは17例(51.5\%)であった。手術術式は、ハルトマン など人工肛門造設16例、腸管切除及び吻合の 1 期的再建 11例、穿孔部単純開鎖 5 例、ドレナージのみ 1 例であっ た。死亡症例は 9 例 $(27.3 \%)$ であり、生存例 24 例と POS SUM score を比較したが術前機能、手術侵㜔、予測死亡 率、予测合併症率、いずれも有意差を認めなかった。考 察：当科での死亡症例は 9 例 $(27.3 \%)$ と決して満足のい くものではなかった。このうち 4 例は大腸癌症例で、す へでか腫場口側ての遊㒕型穿孔であった。内圧の上昇し た口側腸管の穿孔により䔬便が多量に流出したことが予 後不良の一因と考えられた。その他、特発性 3 例、謴瘍 性大腸炎 1 例、S 状結腸喆室炎 1 例で、このうち 3 例は遊 離型穿孔であり、また 3 例は発症から数日経過していた。 しかし POSSUM score上、生存例との有意差かなく更 に検討が必要である。

\section{0-662 特発性横行結腸破裂の一例}

姫路赤十字病院外科

松本祐介，信久徹治，遠藤芳克，渡逶貴紀，甲斐恭平， 山田隆年, 永廣格, 中島明, 石塚真示, 佐藤四三, 中島晃

今回我々は特発性大腸穿孔の中でも比較的稀とされる横 行結腸穿孔の一例在経㓩したので若干の文献的考察を加 えここに報告する。【何例】77歳、女性。【主訴】腹部膨 隆【現病歴】以前より便秘がちであり平成13年には䔬便 性の腸閉塞となった既往あり。病、認知症等で近医入 院中。平成16年12月19日腹部膨隆あり。12月20日腹部単 純レントゲンで free air 多量にあり。加療目的で当科紹 介となった。【入院時現症】腹部全体が剅満しているもの の腹膜刺激症状は認めず。血圧 $108 / 58 \mathrm{mmHg}$ 、脈拍数 103 回/行【画像所見】腹部〔Tにて多量の free airを諮めた。 消化管穿孔部位は不明で、腹水もほとんど認めなかった。

【維温】穿孔部は不明ながら消化管穿孔による汎発性腹 膜炎い言断で開腹術を施行した。【手術所見】腹水はほと んど無く横行結腸は㹡張し白苔の付着した pin hole 状 の穿孔部を認めた。横行結腸を約 $10 \mathrm{~cm}$ 切除し一期的に 縫合した。【病理組織】穿孔部は急性の炎症細胞浸潤を伴 つており、虚血、馣室、悪性所見を記めず特発性結腸破 裂と診断された。また穿孔部の周囲には閉塞性腸炎と類 似した像が散見された。【考察】特発性大腸穿孔の中で横 行結腸穿孔は $6 \%$ と稀であるが、穿孔性腹膜炎の鑑別診 断として念頭に置く必要があると思われた。

\section{0-663} 大腸穿孔のスクリーニングと予後予湘因

子について

大分大学第 2 外科 ${ }^{11}$, 大分大学消化管外科 ${ }^{21}$

田中栄一"'，野口甽2)，菊池隆一"，森山初男"，川原克信"， 猪股雅史 ${ }^{2)}$, 北野正剛2)

【目的】大腸穿孔のスクリーニングとしての画像検査成 績と予後予測因子につき検討した。【症例・方法】1948 年 1 月〜2005年12月の $\therefore$ 年間の大腸穿孔手術症例は18例 であった。内訳は男性10例、女性 8例、平均年齢69.5歳 (36 85)、穿孔部位は右側大腸 6 例、左側大腸 12 例、疾 患崲室（4例）、特発性（4例)、医原性 (3 例) の順 に多かった。死亡率は28\%（5例)であった。（1）CT、 单純 X-pにおける free air の検出状況、(2) 他疾患周 術期症例を除外した16例において年齢、性別、穿孔部位、 穿孔形式、発症からの時間、発熱、ショックの有無、WBC 值、CRP 值、基硞疾患と予後との関連につき検討した。 【結果・考察】(1) 画像検查成續：16例にCT を施行さ れており、内12例に free air を認め、75\%の検出率であ った。これは単純 X-PU18\%。に比へ高かった。（2）予 後予測因子：予後不良の有意の因子は CRP 高值、遊離 穿孔型、心疾患を有するものであった。死亡例で年潞が 高い傾向にあった。【結語】大腸穿孔はスクリーニング にCTが有用であり、CRP 高值、遊砠穿孔型、心疾患を 有するものは重篇である。 
$0-664$

上直腸動脈動脈瘤が原因と考えられた $\mathrm{S}$

状結腸 上部直腸の虚血性腸炎の 1 例

公立昭和病院外科

遠藤大昌, 小山洋伸, 小林隆, 照屋正則

【症例】64歳女性. 肛門痛，便秘を主訴として近医を受 診.下部消化管内視鏡にて S 状結腸の虚血性腸炎と診断 された，保存的加療を続け，内視鏡所見は改善したもの の, 症状は持続，当院に紹介後の内視鏡検查では S 状結 腸の約 $20 \mathrm{~cm}$ 長にわたって緥走謴瘍を認め, 発赤, 浮腫を 伴っていたことからややり虚血性腸炎と診断した.CT では同じ部位に著明な壁肥厚が見られた。下腸間膜動脈 造影を行ったところ, 上直腸動脈の末梢に $1.5 \mathrm{~cm}$ 大の单 発の動脈瘤を認めた。約 2 ヶ月間の保存的治療で改善し
O-666

全結腸に及ぶ壊死性虚血性大腸炎の1例 小松市民病院外科"，山中温泉医療センター2)

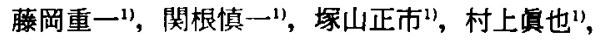
川浦幸光 ${ }^{1}$, 高橋一郎 ${ }^{2\}}$

症例は72歳、男性、主訴は腹痛である。平成18年 1 月 3 日午前 3 時頃より突然主訴を認め近医受診、急性腹症 診断にて手術目的に当科紹介、入院となった。午前11時 WBC7300,CRP0.68であり、腹部 CT検査で明らかな free air を認めないため絶食、抗生剂治療にて保存的に 経過観察していた。午後 6 時頃上り腹痛増強し午後10時 の採血ではWBC6000,CRP13.10,Cr1.9,CPK831と悪 化し、CT 検査では腹水の增量を認めたため 1 月 4 日午 前 0 時上り緊急手術施行した。結腸には穿孔を認めなか つたか、忘腸からS状結腸にかけ連続性に壊死を認め たため大腸亜全摘術、回腸人工肛門造設術を施行した。 病理組織学的には盲腸からS状結腸までの大腸に広。 囲に壤死を認め、壇死は粘膜及び粘膜筋板程度の深さで ある部分が多いが、全層性に壊死に楩った部分も認めら れ、高度かつ広䈥囲の虚血性腸炎として矛盾しない所見 であった。術後释過は良好で手術後第27病日目に軽快啲 院となった。全結腸に及ぶ薯死性虚血性大腸炎の病態は 重篤で術中健常と思われた粘膜に術後さらに壊死の進行 が見られることがあるため予後は極めて不良である。睍 管虚血の進行を防ぐ治療法が望まれるが、現時点では腥 管の壤死が広がか否かを評価する方法がないため、口 側に人工肘門を造設し粘膜面の袮重な観察が必要であ る。全結腸に及ぶ壤死性虚血性大腸炎に対しては大腸典 全摘、人工肛問造設術が唯一の救命手段であり本例でも 有奻であった。

$0-667$ 広範な結腸壤死をきたした壊死型虚血

性大腸炎の一例

洛和会丸太町病院外科

吉井一博, 原田佐智夫, 山本芳樹, 佐藤伸一

症例は心筇梗塞の既往がある75歳女性。平成17年11月14 日夕食後、腹痛、嘔気、嘔吐が出現し、本院救急受診、 入院。11月15日腹部所見及びCT 所見にて虚血性腸炎、 汎発性腹膜炎と診断し、同日緊急手術施行。開腹所見て は盲腸加らら状結腸に至る広範な結腸壤死を認め、結腸 重全摘術 (一期的吻合) を施行。術後経過は概ね良好てあ ったが、11月28日より腸閉塞症を併発した。これは保存 的に改善し、12月19日退院となった。しかし、平成18年 1 月 9 日再び腸閉塞症を発症し、本院入院。内視鏡検㚗 にて残存結腸の虚血性腸炎による腸閉塞症と診断。一旦、 保存的に改善したが、経口摄取再開とともに增悪したた め、1月27日狭部部腸管切除手術施行。狭䆧部は吻合部 から残存 S 状結腸に強く認めたが、口側回腸にも一力所 skip lesion を認めた。術後経過は良好にて 2 月11日退院 となった。

壊死型虚血性大腸炎の中でも全結腸型は非常にまれであ ク、致死㝘も高く、予後不良な疾患である。今回われわ れは発症約 21 時間後に緊急手術 (一期的吻合術) を施行 し、救命し得た全結腸型壊死型虚血性大腸炎の一例を経 験したので若干の文献的考察を加え、報告する。 
$0-668$

腸管壤死を来した大腸カンジダ症の 1 例 石切生喜病院外科"，大阪市立大学肝胆膵外科 ${ }^{23}$ 山本隆嗣 1 , 大野耕一"1, 上西崇弘 ${ }^{11}$, 石原寞治 ${ }^{11}$, 西田達 ${ }^{2}$, 宫本裕子", 渡辺千絵" ${ }^{1}$, 三上慎一 ${ }^{21}$, 池辺孝 ${ }^{21}$, 田中肖吾 ${ }^{2}$, 市川剛 ${ }^{2}$, 裴正寛 ${ }^{2}$ ，塚本忠司 ${ }^{2}$, 広橋一裕 ${ }^{2)}$, 久保正二 ${ }^{21}$

症例は72才、女性。大動脈弁閉銷不全、狭心症、慢性関

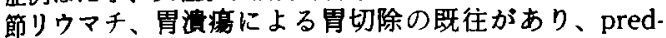
nisolone $10 \mathrm{mg} /$ 日、 methotrexate $6 \mathrm{mg} /$ 週の長期内服 歴があった。直腸脱に対し Ripstein 法手術を施行、術後 はやや便秘気味であった。術 3 ケ月後、腹部㜆满感と筋 性防御を伴う腹痛を主訴に来院した。38度の熱発を認め、 CRP $11.6 \mathrm{mg} / \mathrm{dL}$ 、WBC $13870 / \mu \mathrm{L}$ (Seg $60^{\circ}$ 。. Stab $26 \%$, lympho $5 \%$ )であった。腹部 X 線写真や CT 上、 結腸を主とする鼓腸があり、Douglas 窝に腹水を認め た。何らかの腸管壊死を疑い、緊急開腹した。透明な腹 水を少量みとめ、S 状結腸が状に壊死に宿っていた。 Hartmann 手術を施行、病理組織検查てカンジダ感染に よる腸管壊死と判明した。食道、睦、肺、心などに真菌 感染の無いことを確認し、itraconazole 200mg/日 4 週 間投与、全身状態は軽块し、術1.5ヶ月後に退院となった。 現在リウマチはは NSAIDによるコントロールを行って いる。大腸カンジダ症は低免疫状態の患者に他搰器の力 ンジタ症とともに希に発生することがある。自駼例では 便秘と免疫抑制剂の長期投与が発生母地になったと思わ れる。自験例の様な低免疫状態の急性腹症の症例ではウ イルスや真菌などの腸管感染なども念頭に置き監別診断 を行っていく事が肝要であると考えられた。

\section{0-669 当院で経験した静脈硬化性大腸炎の3 例 広島記念病院外科}

清水亘, 宮本勝也, 中村有美, 藤本三喜夫, 横山雄二郎, 森藤雅彦, 中村浩之, 武藤嵲, 中井志郎

【はじめに】静脈硬化性大腸炎は静脈硬化に起因した還 流異常による虚血性大腸炎で、比較的稀な疾患である。 今回我々は、2002年〜2006年まてに、3 例の静脈硬化性 大晹炎を释験したので報告する。【症例】年龄は56歳〜77 歳(平均64.7歳)、3例とも女性であった。イレウス症状 を記めたのは 2 例で、残り1例は腹痛のみであった。ま た、全ての症例に漢方薬（詳細不明）の長期服用歴があ つた。診断には腹部エコー、CT、注腸、CF (病理㭘査) が施行され、エコー及びCTでは、全ての症例で右側結 腸の壁肥厚七壁内石灰化を認め、注腸では、2 例は八ウ ストラの消失と結腸の硬化像が見られた。CFにおいて、 全症例に青黒色調で血管網が消失した浮腫状粘膜の連繶 と数箇所のびらん、謴瑒が存在し、病理娭査にて、粘膜 固有層に太いコラーゲン線維の增生、毛細血管壁の肥厚 を訊め、静脈硬化性大腸炎に矛盾しない所見であった。 以上より 3 例とも静脈硬化性大腸炎と診断された。治療 は、イレウス症状を呈した 2 例は腹腔鏡併用上行〜下行 結腸切除術が施行され、良好な経過を得ている。また腹 痛のみの1例は、保存的治療にて外来つォロー中であり、 現在のところ病態の増悪は認めていない。【まとめ】この 度経験した 3 症例全てに、漢方薬の服用歴を認めた。2 例に手術を施行し、良好な経過を得ている。よって、イ レウスを練り返す症例には、外科的手術の良い適応と考 えられた。
0-670 マントル細胞リンパ遁に0-157出血性大

腸炎を合併し，重症化した一例

多根総合病院外科"1，多根総合病院救急部 ${ }^{21}$

柳英雄 ${ }^{1}$ ，丹羽英記 ${ }^{1)}$, 廣岡紀文 ${ }^{11}$, 錦織英知 ${ }^{11}$, 小川漳宏 ${ }^{11}$,

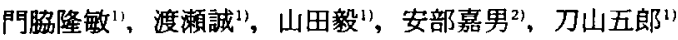

マントル細胞リンパ腫は1992年に Banksらにより提唱 された, mantle zone 由来のリンパ腫であり, 組織学的 には低悪性度に分類されるが臨床経過は不良であり，生 存期間中央值は $3 \sim 5$ 年とされている. 今回我々は $0^{-}$ 157出血性大腸炎を契機にマントル細胞リンパ腫と診断 された一例を経験したので若干の文献的考察を加えて報 告する，症例は62歳男性で下血を主訴に来院した。補菠 下に絶食とし，FOM 静注を行なうも下血が頻回となり， 腹膜炎症状が增強した為，緊急に開腹手術を行なった。 術中所見では後腹膜から腸間膜に及ぶ著明な浮腫を認 め，傍腸管リンパ節から大動脈周囲リンパ節にいたるま で多数のリンパ節腫大を認めた。回盲部の腸管壁は著明 に発赤腫脹していた為に回盲部切除を行なった。摘出し た腸管の回盲部は極度に肥厚し粘膜面より屚慢性に出血 像を認めたが，ポリポーシス様の所見は認めなかった。 術後に便培責よりO-157を検出し，術後 5 日目に敗血症 性ショック・急性腎不全を発症するも集中治療室管理に より術後43日目に軽快退院した。術中リンパ節標本より マントル細胞リンパ腫の病理診断を得た。出血性大腸炎 の重症化にマントル細胞リンパ腫による免疫不全が関与 していたものと思われう。

0-671 結腸垔全摘を施行し救命しえた䔬便性イ レウスによる閉塞性大腸炎の 1 例

国保古座川病院

山出尚久，樫谷益生

我々は，急激に発症した䔬便性イレウスによる閉塞性大 腸炎の 1 例を経験したので報告する。症例は85歳女性。 2001年12月中旬転倒し, 胸骨骨折・第 4 腰椎変性すへりり 症と診断され，12月21日当院整形外科入院となった。12 月25日朝より腹痛を訴え。13時頃突然ショックとなり外 科紹介となった。CT上S゙状結腸以下に樭便塊を認め、口 側結腸は著明に拡張していた。急激な経過とCT 所見よ り大腸粫または䔬便による閉塞性大腸炎を疑い，緊急手 術を施行した。開腹すると, $\mathrm{S}$ 状結腸〜直腸にかけて硬い 烡便塊を触知し，その口側結腸は著明に拡張していた。 横行結腸中央部の墏膜面は壞死に陥っていたが，その他 の結腸蛪膜面の色調に異常は認めなかった。まず壤死に 陥った横行結腸を切除したが，切除断端の粘膜面は口 側・肛門側ともに範囲に壊死に宿っていたため，結腸 要全摘を施行し，回腸にて人工肚門を造設した。切除標 本では盲腸〜S 状結腸途中まで粘膜面は連続性に壊死に 陥っていたが, 切除断端より䄪 $20 \mathrm{~cm}$ は正常粘膜で, 癌な どの腫瘍性病変は認めず，黄便性イレウスによる閉塞性 大腸炎と診断した。術後敗血症・急性腎不全となったが 治寮により救命しえた。閉塞性大腸炎は，獎膜面から

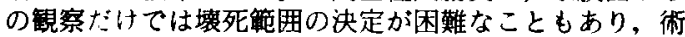
中の十分な観察と壤死腸管の確実な切除が必要と考えら れた。 
性大腸炎の1例

伊賀市立上野総合病院外科

福浦竜樹, 杉平宣仁, 石井雅昭, 久保宏幸

1 例

医療法人健康会京都南病院

鹪野留美，廣間文彦，陳明俊，相馬祐人，清水聡

患者は、64歳男性。平成17年12月10日午後 6 時頃より腹 痛と㖶吐が出現し、当院救急外来を受診。来院時理学的 所見では、腹膜刺激症状は認めなかった。また、腹部 CT 検査で結腸の拡張を認める以外、腹部 X 線検查・血液検 查所見に特記所見は認めなかった。注腸検查では、S状結 腸内に多量の便塊を認め、これが腹痛の原因と判断し保 存的治療を開始した。入院後、頻回の下痢が出現し腹痛 はやや軽減するも、腎不全が出現し、CRP は著明に上昇 した。再度行った腹部 CT 検査では、結腸の拡張は消失

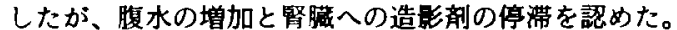
以上より原因不明の大腸炎及び急性堅不全と診断し、以 後、透析・人工呼吸を含めた集中治療が行われ、約 2 週 間後には全身状態は安定した。ただし下䏀と腹痛は続い ていた。その後の MRI 拡散強調像にて左側大腸の強い 炎症が示咬され、大渴内視鏡検查を行い、S状結腸癌と診 断し待機手術を行った。術中所見で腫演の口側約 $5 \mathrm{~cm}$ より口側の腸管粘膜の壊死を確認し、閉塞性大陽炎の併 発と診断。全大腸を検索後、左半結腸切除術を行い、横 行結腸・直腸を一期的に吻合した。病理組織学的検査て は、左半結腸の血流不全と診断された。以上、診断に難 㱑したか内科的・外科的治療にて軽快した S 状結腸癌に よる閉塞性大腸炎の1 例を経験し報告した。

\section{0-673} 右側結腸㮩室炎の臨床的検討

\section{秦野赤十字病院外科}

林勉，鈴木弘治，連尾公篤，神康之，玉川洋

【はじめに】右側結腸㴧空炎は急性虫垂炎との鑑別が困 難で、虫垂炎の診断て乎術が行わ机術中、敨室炎と診断 されることも多い。【目的】右側結腸息室炎において保存 的治療症例と下体行われた症例の治療経過に差がある 加娭討寸る。【社】2003年1月から2005年12月まで当科

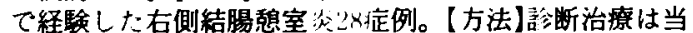

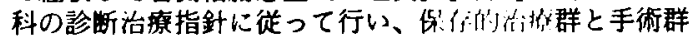
に分け、初診時の臨床所見と治療期間との関係および治 療経過を retrospective に娭討する。【結果】保存的治療 症例18例、手術症例10例、部位別て沬上行結腸20例、盲 腸 $\times$ 例、保存的治療症例では上行結腸 15 例、盲腸 3 例、 手術症例では上行結腸 万例、盲腸 5 例であった。手術症 例10例中 9 例は、急性虫垂炎の診断で手術が行われた。 入院時診断で腸憩室炎であったのは19例 (6て.9\%)で このうち 1 例に手術が行われた。全症例において初診時 の白血球数、CRP 值、腹部所見と治療日数の間に相関は なかった。保存的治撩群の初診時白血球数 $12300 、$ CRP 7.5、絶食期間8.3日、入院期間14.3日であった。手術群 の白血球数 $1156 \%$ 、CRP $\times$.3、絶食期間8.2日、入院期間 16.1日であった。【まとめ】保存治療群と手術群で初診時 の臨床所見および治療経過に差は認められなかった。

小児の右下腹部に腹膜刺激症状を呈する急性腹症では急 性虫垂炎等種々の疾患の鑑別が必要であるが、小愳の大 腸愁室炎は稀で本邦の報告例は知りえた範囲では 6 例で ある。今回我々は11歳の上行結腸款室炎を経験したのて 報告する。症例は11歳女児。主訴は右下腹部痛。来院前 日に心㸗部痛があり、右下腹部痛と発熱が出現したため 来院。右下腹部に腹膜刺激症状、血液検查で炎症反応の 上昇を認めた。腹部エコーでは虫垂の管腔構造は描出で きず、また上行結腸の壁肥厚も認めなかった。年齢より 虫垂炎を疑ったが、確定診断できず抗生剂投与で経過を 見た。翌日腹痛、発熱が増悪したためCT 検査を行った ところ上行結腸下部から盲腸にかけての浮腫と周囲の炎 症像を認め、大腸憩室炎も疑われたが、急性虫垂炎を否 定することができず、腹腔鏡を施行した。衍中所見は少 量の腹水を認めたが虫垂に炎症はなく、盲腸から上行結

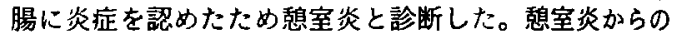
炎症の波及の恐れがあり、腹腔鏡下に虫垂を切除して終 了した。術後経過良好で第10病日に退院となった。術後 28日目に大腸内視鏡検查で上行結腸䕀室炎の所見を確訳 した。本症例はこれまで報告されている大腸悡室炎ては 最も若年の11歳である。小児の大腸㮩室炎は大変稀であ るが右下腹部痛を旺する急性腹症の際に考虑する必要が あると考える。

\section{0-675}

門脈ガス血症を合併した S 状結腸䅫室

炎の一例

京都桂病院外科

平田義弘, 上原正弘, 松谷泰男, 王子裕東, 竹村一徳, 清水正樹, 間中大, 野口雅滋

症例36藏男性、2005年 6 月13日より下腹部痛を主訴に近 医受診し、尿路結石の診断にて経過観察されるも症状改 善を認めず、6月18日当院外来受猃。CTにて S 状結腸想 室炎の診断にて入院し絶食、抗生剂にて経過良好であり、 食事を再開。その後も腹痛、発熱など症状を認めなかっ た。6月26日注腸透視のため前処置を施行。その後39度 を超える発熱を認め、27日 0 時より激烈な上腹部通を認 めた。CTにて門脈ガス血症を認めたが、腹腔内 Free air は認めなかった。惒室炎の腹膜への穿通と考え、同日緊 急手術を施行した。術中所見は、腹腔内に污染を認めず、 少量の腹水のみであった。 $\mathrm{S} \sim \mathrm{Rs}$ 周囲に壁肥厚を認め、 この部位が喤室炎で今回の症状の原因と考えられたた め、この部位より中枢側で人工肛門造設術を施行した。 術後経過は良好であった。7月6日のCTにて門脈ガス は認めなかったが、憄室炎は完全には消退していなかっ た。血液㭘查上炎症反応は正常化していたため退院。蒩 室炎で門脈ガス血症を合併することは稀である。今回発 症後まもなくCTにて診断し、早期手術にて治療した一 例を経験したので報告する。 
を施行した 1 例

\section{美温市立美湌病院外科}

阪本研一，村瀬勝俊，木村真樹，関野誠史郎

【はじめに】炎症性腸疾思に対する大腸切除術では炎症 や㭸着の程度により時として手技的難易度の高い症例に 逼遇する。今回我々は、大腸欯室炎を併発した大腸良性 腫㾇に対して腹腔鏡下大腸切除術を施行した 1 例を経験 したので報告する。【症例】57歳、男性。2ケ月前より排 便回数が多くなり前医を受診した。大腸内視鏡検査で多 発性大腸ポリープと診断されポリペクトミーを施行され たが、S 状結腸の $1 / 2$ 周性 Is 型ポリープの切除目的で 当科を紹介された。注腸造影検查で Rs を中心にS 状結 腸から直腸 Raに多発想室を認めた。血夜検査で炎应反 応を認めなかった。型通りポートを設置し内側アプロー 手て手術を開始した。Rsを中心とした S 状結腸から直 腸 Ra の腸管壁の肥厚が著明で腸管把持に難沾し、仙骨 前面から骨盤腔左壁の炎症所見が強く生理的虽離層の確 認は不可能てあった。炎症性に一塊となった超手拳大の 直晹が骨盤空内を占居し骨盤腔左壁と病着していた。肥 厚のない部位で腸管を切除し、左下腹部 $5 \mathrm{~cm}$ の小切開 下にDST で吻合した。手術時間 4 時間、出血量 $80 \mathrm{ml}$ 。術 後経過良好で術後10日目に退院した。【結語】大腸憩室炎 に対する腹腔鏡下手術では、定型化した手技が要求され る大腸癌に対する手技とは異なった配慮が必要であると 思われた。

0-677 発症から 1 年以上経過した後にCTで診 断しえた魚骨穿通による腹壁内掯晹の 1 例 㕕島聥信病院外科

吉川武志，杉山悟，因来泰彦，清水康庴

異物を誤瞙した場合、此較的稀に消化管穿孔や穿通を起 こし、腹膜炎を発症したり、慢性的に腹肤内腫留、脿癌 を形成したりすることがある。本邦では食習慣から魚骨 による消化管異物が最も多いとされている。今回、魚骨 による消化管穿孔を生じたが、腹膜炎に至ることなく柽 快し、長期間経て腹壁脹場として発症した 1 例を経験し たので報告する。症例は73歳女性。1 年はど前から腹部 の不快感、異和感を自覚し、近医を受診。上部・下部消 化管内視鏡検査、胸腹部 CT、腹部超音波検査などを受け たが明らかな異常は認められなかった。過敏性腸炎と考 えられ、投薬を受けていた。途中一時期症状が軽減した が、再び出現し、次第に痛みを自党するようになった。 3 週間ほど前よりは左下腹部に痛みを伴う腫㾿を自覚し た。应状が増悪したとして大腸内視鏡検查を再び行った がポリープのみで他に明らかな異常所見は認めず。同娭 查後より症状が增悪した。検査より6日後に当院を受診 され、腹部 CT にて腹壁聩痽内に魚骨を疑う線状の高港 度域を認めた。魚骨穿通による腹壁内晨掦の診断で当科 稆介となり、緊急に手術を施行した。膿晹は腹壁と横行 結腸とに強固に付着していた。一部腹壁を合併切除し、 膿埸を含めた横行結腸部分切除術を行った。魚骨は横行 結腸の粘膜を完全に貫通し、結腸内腔側は正常粘膜で覆 われていた。啧傍を切開したところ内部より魚骨が得ら れた。術後経過は良好であった。
0-678 肛門直腸異物の 6 例

社会福祉法人聖焉会聖需病院中央手術部"), 社会福祉法

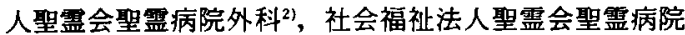
小児外科

今澤正彦11，日比健志 ${ }^{21}$ ，野々山益雄 ${ }^{21}$ ，中村司 ${ }^{31}$

【目的】当院における肛門直腸異物症例のうち、検索し 得た 6 例について、若干の考祭を加えて報告する。【症例】

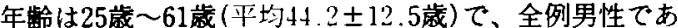
つた。【結果】4例(66.7\%)に配偶者が有ったが、一方て 配偶者の無い 2 例のうち 1 例 $(16.7 \%$ o $)$ 離婚歷が有り、 1 例 $\left(16.7^{\circ}\right.$ \%)には結婚歴が無かった。異物の実体は、木 製の箸、飲料水の瓶、スプレイの蓋、ヴァイブレータ、 車載用発煙筒であった(他の 1 例は異物の詳細を検索し 得ず)が、5例 $\left(83.3^{0}\right.$ ）て挿入の契機・動機を聴取出来な かった。異物の主坐は、4例 $\left(66.7^{\circ}{ }_{\mathrm{o}}\right)$ で直腸、2例(33. $3 \%$ )で肛門であった。全例で経肛門的な除去が可能であ ったが、術後合併症として、直腸粘膜損傷が 1 例(16.7\% ) に、肛門損伤が1例 $(16.7 \%$ \%)に見られた。異物除去後 1

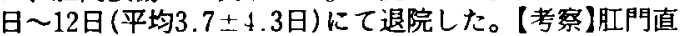
腸異物症例は、大腸穿孔に至る恐れも有るなど、外科診 療の対象となる一方、特異な病歴を有しがちなことに伴 う配虑も要する。肛門直腸異物症例 診瘄について、若 干の文献的考察を加えて報告する。

\author{
0-679 盲腸の粘膜下腫㾮として切除された腸管 \\ 子宮内膜症の一例 \\ 長野県厚生連策/井総合病院 \\ 浦川雅己，宮本英雄，古澤徳彦、池野龍雄，市川英幸
}

【症例】37歳女性【既往歴】5歳時に隔桃腺切除術、 31歲時に大腸ポリープに対してポリペクトミー施行、32 歳時に子宮内膜症にて腹腔鏡下に内膜症切除術と右の卵 管切除術が施行されている。【現病歴】平成11年以降大腸 ポリープに対して定期的に大腸内視鏡て経過観察されて いた。平成16年 6 月に盲腸の粘膜下腫瘍が認められた。 小病変でったため経過観察とされたが、平成18年 3 月 の下部消化管内視鏡施行時に嗹瘍の增大が認められた。 CTでは病変は局所にとどまっており、盲腸 GIST か虫 垂の粘液腫が疑われた。平成18年 4 月に手術目的にて入 院となり、腹腔鏡補助下回盲部切除術を施行した。摘出

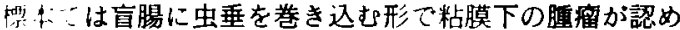
られた。術後経過は概ね良好で術後11日目大きな合併症 なく退院となった。病理結果では異所性の子宮内膜症て あった。【考察】腸管子宮内膜症は比較的まれな疾患で全 子宮内膜症のうち $12 \%$ 。ぼを占める疾患である。局在と しては S 状結腸と直腸には多く7割を占める。本症例の ような盲腸を局在とするものは少ないといわれている。 若い女性の腸管の腫痬としてはまれであるが鑑別診断と してあげるべき疾患と考えられた。盲腸を主座と寸る腸 管子宮内膜症の一例を経験したので若千の文献的考察を 加えて報告する。 
0-680 著明な直腸狭窄のため、2 期的手術が必

要であった直腸子宮内膜症の1例

総合守谷第一病院外科"，筑波大学消化器外科2)

丸山常彦"1，高垣俊郎"1，市村由佳子"1，大河内信弘21

今回われわれは、著明な直腸狭窄のため、人工肛門造設 術と直腸切除術を 2 期的に施行した直腸子宮内膜症の 1 例を経験したので報告する。症例は38歳女性。1992年よ り子宮内膜症に対してホルモン療法を行っていた。2004 年 2 月頃より便秘と下痢を繰り返すようになった。2006 年 4 月 3 日上り排便が見られなくなり、4月11日に下郕 を内服したところ、激しい腹痛を認めたため、当院を受 診した。腹部しT 一大腸内に多量の便塊を認め、直腸 Rs に腫㾺が疑われる病変と同部位での直腸狭寍が疑われ た。大腸ファイバーて直晹 Rsに届曲、狭鉒を認めたが、 粘膜面は浮腫を認かるのみで悪性腫鹄を疑う所見は認め なかった。ファイバーは通過せず、経肛門的イレウス管 を挿入し、腹痛はわずかに軽快した。しかし、大腸内に 残存した便塊は多管であり、経肛門的イレウス管のみて は排出できないと判断し、S状結腸に人工肛門造設術を 施行した。排便は良好で経口も可能となり、人工肛門造 設術後21日目に决寉部に対する直腸切除術を施行し、術 後11日目に退院となった。病理検査で直腸子宮内膜症と 診断した。腸管内膜症は比較的まれな疾患ではあるが、 下部消化管疾患の军別診断では忘れてはならない疾患て ある。

$0-681$

直腸脱にて直腸粘膜壊死し手術を要した

一例

名古幄市立大学臨床病態外科

坂本雅澍，高橋広城，松尾洋一，若杉健弘，山本棯，

高山悟，沢井博純，佐藤幹則，岡田祐二，赤毛義吉，

竹山廣光，真河忠卡

直腸壤死にて手術を必要とした、直超脱の一例を経験し た。【症例】缃男性【既往歴】20歳虫垂炎手術、60歳胆 石症手術、70歳府核手術【【仍歴】特記事項なし【現 病歴】5 日前より直腸脱があり、近医にて整復するもす くに脱出するひて入院にて様子観察をしていた。徐々に 腹满增強し、直腸壤死、イレウフの診断で当院紹介転送。 入院後経過 肛門よりうっ血した直腸粘膜が脱出してお り、一部が壤死していると考えられた。また発熱、血液 検查で炎症反店の上昇しあり、直腸塭死の診断て手術施 行した。【手術所見】下腹部正中切開にて開腹。腹腔内に は淡赤色透明の腹水が存在していたが、腹腔内腸管に血 行障害や壇死は見られなかった。腹会陰式直腸切断術、 $\mathrm{S}$ 状結腸人工肛門造設を行った。【標中所見】肉眼的には 歯状線より口側 $5 \mathrm{~cm}$ は直腸粘膜が褧名脱落していた。 その口側に直腸粘膜か;腫㨨を 2 か所形成していたが、組 織学的には血括开泌、炎症緗胞浸潤のみで悪性所見は見

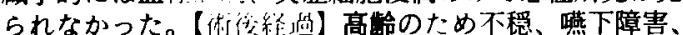
肺炎発症したが軽快し、術後39日で軽快退院した。以上 の症例に対し若干の文献的考察杂加え報告する。
0-682完全直腸脱に対するDelorme 法十人工 靶帶を用いたThiersch 法による一期的手術 洛和会音羽病院大腸肛門科

野村英明，加川隆三郎

直腸脱の治療には経肛門的、経腹的に樣々な術式が報告 されており、現在本邦では経肛門的術式として直腸粘膜 縫縮術の Gant-三輪法、あるいはそれに肛門輪䋖縮術の Thiersch 法を組み合わせた方法が普及している。しか し、粘膜のみの縫縮である Gant-三輪法は早期再発の可 能性も高く、Thiersch 法も使用するマテリアルにまだま だ考慮の余地が残る術式である。我々は完全直腸脱に対 する経肛門的術式として、筋層の縫縮を行う Delorme法 に伸縮性のある人工勒帶を使用するThiersch 法を併用 した一期的手術を選択しており、今回、本術式の治療成 績を報告する。【対象と方法】当院で2005年 6 月から現在 までに全身麻酔下に Delorme 法十Thiersch 法で手術を 施行した完全直腸脱 9 例。男性/女性：1例 / 8 例初回 手術例 $/$ 再手術例：6 例 $/ 3$ 例年砱：38 86歳 (平均71. 6歳) 以上の症例を retrospectiveに検討した。【結果】全 例、術後に脱出が消失し、便失禁についても改善傾向に あった。FISI (Fecal incontinense severity index) score についても改善を認めた。合併症及び再発は今回の检討 症例中には経験しなかった。結論】現在のところ合併症、 再発例は無いが、今後症例を重ねるとともに長期予後の 観察が必要であると考えている。

0-683 カルチノイドを合併し急性虫垂炎症状を 呈した子宮内膜症の一例

関西医科大学付属病院高度救命救急センター", 神戸大 学災害・救急医学 ${ }^{21}$

前田裕化"，高橋晃 ${ }^{21}$, 石井昇 ${ }^{21}$

虫垂炎症状で発症した子宮内膜症の報告は散見される が、更にカルチノイドを合併した一例を経験したので報 告する。症例は35歳、女性。宗祖は右下腹部痛。既往歴 として 6 年前よりSLEで当院免疫内科に、2 年前よりパ ニック障害にて当院精神科に通院中で、ステロイド用を 内服中であった。現病歴は 2 日前より右下腹部痛を自覚 してていたが放置。症状が持続するため前医を受診、腹部 CT上虫垂周囲に炎症像老認めるため急性虫垂炎の疑い にて当院救命救急科を紹介され、受診となった。来院時 意識清明、体温 37.2 度。腹部は平坦、軟も右下腹部に強 心压痛と Blumberg 徴候を認めた。白血球は6300と正常 範囲内も CRP は $2.60 \mathrm{mg} / \mathrm{dl}$ と軽度上昇していた。腹部 超音波検査て虫垂先端に萁石様䧔影を認め、手術適応と 判断し同日全身麻酔下に緊急手術を施行した。術中所見 では虫垂は腫大しており、先端にゼリ一状の付着物を詪 めた。順行性に虫垂摘出術を施行し手術を終了した。術 後の経過は良好で術後10日目に退院となった。術後病理 標本にて虫垂壁の間質内に子宮内膜組織を認的、子宮内 膜症が虫垂炎様の症状をきたしていたものと考えられ た。更に粘膜内に約 $1 \mathrm{~mm}$ 微小な病変も認め、免疫染 色で synaptophysin, chromogranin,CD56いずれも陽性 であり、カルチノイドを合併していたことも判明した。 